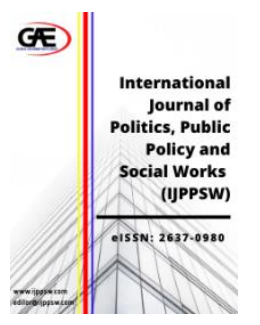

\author{
INTERNATIONAL JOURNAL OF \\ POLITICS, PUBLICS POLICY \\ AND SOCIAL WORKS \\ (IJPPSW) \\ wWw.ijppsw.com
}

\title{
THE EFFECT OF POLITICAL BRAND EQUITY ON YOUNG THAI VOTING INTENTION: A STUDY OF FUTURE FORWARD PARTY
}

\author{
Labuda Mad-A-Dam ${ }^{1 *}$, Syamsyul Anuar Ismail ${ }^{2}$ \\ 1 School of Multimedia Technology and Communication (SMMTC), Universiti Utara Malaysia, Kedah Malaysia \\ Email: labuda_madadam@ahsgs.uum.edu.my \\ 2 School of Multimedia Technology and Communication (SMMTC), Universiti Utara Malaysia, Kedah Malaysia \\ Email: syamsul@uum.edu.my \\ Corresponding Author
}

\section{Article Info:}

Article history:

Received date: 01.12.2021

Revised date: 15.12 .2021

Accepted date: 26.12.2021

Published date: 31.12 .2021

\section{To cite this document:}

Mad-A-Dam, L., \& Ismail, S. A. (2021). The Effect Of Political Brand Equity On Young Thai Voting Intention: A Study Of Future Forward Party. International Journal of Politics, Publics Policy and Social Works, 3 (10), 01-10.

DOI: $10.35631 / I J P P S W .310001$.

This work is licensed under CC BY 4.0

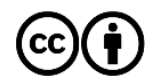

\begin{abstract}
:
Political branding is an essential duty to present ideology, policies, image of a political party to the electors. Therefore, the party brand equity in political branding is enhances property, reliability and extent the strength of political brand. Both of strategies are influence on the remembrance and voting intention of the young generation. As well as, increase opportunity to achieve in an election. The research purposes to examine (1) the components of party brand equity are party brand image, awareness, quality, loyalty and leadership have a significant relationship influence on voting intention of the young generation (2) to investigate that the party brand attitude mediates on the relationship between the components of party brand equity and voting intention of the young generation. The research findings indicate that the components of party brand equity have a significant relationship on voting intention of the young generation and party brand attitude has a significant mediates on the relationship between the components of party brand equity and voting intention of the young generation.
\end{abstract}

Keywords:

Political Branding, Party Brand Equity, Political Marketing, Branding, Voting Intention

\section{Introduction}

Future Forward Party is a new generation political party. The political party was founded by Mr. Thanathorn Juangroongruangkit on March 15, 2018 (FFP, 2018a). The model of FFP purposes to active political attention and awareness of the party brand image to the young Copyright $\odot$ GLOBAL ACADEMIC EXCELLENCE (M) SDN BHD - All rights reserved 


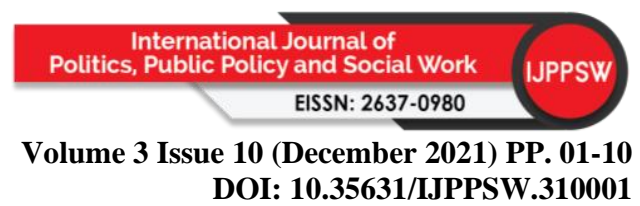

generation through social media (BBC, 2019a; McCargo, 2019; Olarn \& Mackintosh, 2019; Regan \& Olarn, 2019; Wongratanawin, 2018). The political party represents orange theme color consistent with a modern logo, young leader, and candidates. Also, clarify slogan and ideology as well as promote political party as a democracy political party (FFP, 2018b). On March 24, 2019, Thailand has conducted a general election with a total of 81 political parties (BBC, 2019b) and 46 new political parties including the FFP (ECT, 2019b) have participated. The official result of the Thailand 2019 general election announced that the FFP received 6.2 million popular votes, in the third-ranking of the election (ECT, 2019b). Hasuwannakit (2019) and Kannika (2019) found that young generation in the aged below 20 to 30 years satisfied and supported the FFP. Moreover, very few of new political parties are achieved in the election. Thus, a logo designer of the FFP believed that the political branding is reflecting political position, ideology, attitude of a political party and influences remembrance of the electors (Areepermporn, 2019).

\section{Literature Review}

\section{Political Branding and Party Brand Equity}

Political brand is represents concept of ideology, policies, information and image of a political party (Pich \& Armannsdottir, 2018) includes symbol, logo, the name of political party, slogan and color theme (Marland, 2013). These components of political brand aim to sell the political party candidates as a product (Guzmán et al., 2015), expect the electors to purchase while the elector is a consumer (Suyitno, 2013). Party brand equity is an associated and enhances property and reliability on the political branding. Party brand equity relates to political brand name, extent the strength of party brand loyalty, party brand quality, party brand awareness and party brand image (Achor et al., 2017; Alkhawaldeh \& Halim, 2015a). The essential strategy of party brand equity is added value in the political brand to represent main concept and communicate to the elector through advertising techniques (Scammell, 2007). Party brand equity influences change of elector's perception and voting intention (Almohammad, 2014; Scammell, 2007). Thus, party brand equity is the process of the electors would provide vote or abstain to a particular political party in the form of vote behavior (Alkhawaldeh \& Halim, 2015b; Scammell, 2007).

\section{Party Brand Image to Voting Intention}

Party brand image is associated among the political party characteristic (Alkhawaldeh et al., 2016b), personal image and service (Phipps et al., 2010). Party brand image using psychology to represent perception and emotion of political brand (De Landtsheer \& De Vries, 2015) to attract the elector (Pich \& Armannsdottir, 2018). Party brand image is a predictor of vote intention and elector choice (Achor et al., 2017; Upadhyaya \& Mohindra, 2012). Similarly, Suaib et al. (2017) identified that party brand image has positive significant relationship on satisfaction of the electors. Therefore, the research purposes to examine the relationship between party brand image and voting intention of the young Thai generation as hypothesis follow:

H1: Party brand image has a significant relationship with voting intention

\section{Party Brand Awareness to Voting Intention}

Party brand awareness is a leverage of communicate with the public to recognize by adopted communication techniques and recall strategy to administrate remembrance of the electors (French \& Smith, 2010; Harris \& Lock, 2001; Phipps et al., 2010). Party brand awareness can reduces confusion of the electors in making decision. So, party brand awareness effects vote 


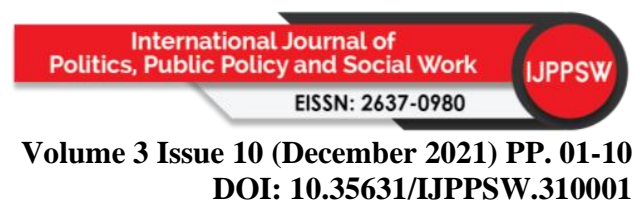

intention of the electors (Alkhawaldeh \& Halim, 2015b). According to Alkhawaldeh et al. (2016a) agree that, party brand awareness is capability to create aware and recall in the mind of electors relate to a particular political party or candidate. Thus, an objective of the research is to investigate the relationship between party brand awareness and voting intention of the young Thai generation as hypothesis follow:

$\mathrm{H} 2$ : Party brand awareness has a significant relationship with voting intention

\section{Party Brand Quality to Voting Intention}

Party brand quality is the entire expectation of the political brand in the perception of the electors (Alkhawaldeh \& Halim, 2015a). Party brand quality is an essential strategy increase opportunity to win an election (Alkhawaldeh et al., 2016b). Because, electors estimate the entire performance and perceived quality of political brand through party brand quality. Thus, party brand quality is an important factor and direct impact on voting intention (Alkhawaldeh et al., 2016b; French \& Smith, 2010). Therefore, an objective of the research is to identify the relationship between party brand quality and voting intention of the young Thai generation as hypothesis follow:

H3: Party brand quality has a significant relationship with voting intention

\section{Party Brand Loyalty to Voting Intention}

Party brand loyalty is the concept of re-vote or repeat to vote in a particular political party in an election and recommend the preferred political party to other electors (Alkhawaldeh \& Halim, 2016; Schofield \& Reeves, 2015). Party brand loyalty can attract the attention of elector (Alkhawaldeh et al., 2016a) and impact on making decision of the elector (Dick \& Basu, 1994). Schofield and Reeves (2015) and Campbell (1960) proposed that party brand loyalty has a significant relationship on the perceived performances of political party and influences voting intention. Then, an objective of the research is to examine the relationship between party brand quality and voting intention of the young Thai generation as hypothesis follow:

H4: Party brand quality has a significant relationship with voting intention

\section{Party Brand Leadership to Voting Intention}

The definition of brand leadership is the prominence of a brand relates to brand equity and attract to perception of consumer (Chang \& Ko, 2014; Chiu \& Cho, 2019). However, the statement above can refer to political dimension. The structure of party brand leadership is a combination of trend, vision, the impact of communication, brand achievement and brand position (Chang \& Ko, 2014; Chiu \& Cho, 2019). Brand leadership has a positive significant relationship on purchase intention (Chiu \& Cho, 2019). This view is supported by Busch (2016) the strong political party standing position has an impact on the confusion of the electors. Thus, the research aims to investigate the relationship between party brand leadership and voting intention of the young Thai generation as hypothesis follow:

H5: Party brand leadership has a significant relationship with voting intention

\section{Party Brand Attitude and Party Brand Attitude as a Mediator}

The consumers are assessment the entire brand through brand attitude (Melewar et al., 2007; Olsen et al., 2014; Vogel \& Watchravesringkan, 2017). The brand attitude attracts consumer using psychology. The psychology approach is affective process into attitude and cognitive information process (Bhatta, 2016; Olsen et al., 2014; Pradhan et al., 2016; Vogel \& Watchravesringkan, 2017). In the political dimension, party brand attitude is the electors evaluate on the entire political brand. And, the emotions of the electors determined by favorable or unfavorable to the political brand. So, party brand attitude is increasing the stimulus of the Copyright (C) GLOBAL ACADEMIC EXCELLENCE (M) SDN BHD - All rights reserved 


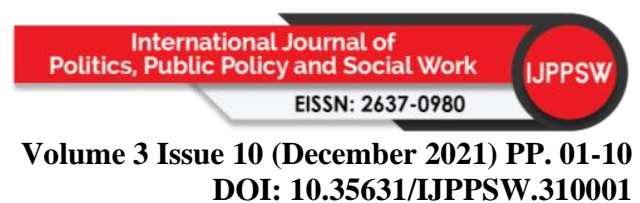

elector (Pradhan et al., 2016). Therefore, party brand attitude is an essential strategy to adopt in the political branding for enhances voting intention of the elector (Kudeshia \& Kumar, 2017). However, several researches were applied brand attitude as a mediator to analyze purchase intention. Refer to Pradhan et al. (2016), the brand attitude is an essential role to mediate among consumer, brand, and celebrity relate to purchase intention. The qualification of party brand attitude is appropriate to be a mediator on the relationship between the components of party brand equity and voting intention of the young generation. The components of party brand equity refer to this research are party brand image, awareness, quality, loyalty and leadership. The research also purposes to identify the relationship between party brand attitude and voting intention. As well as, to determine the mediation effect of party brand attitude on the relationship between party brand image, party brand awareness, party brand quality, party brand loyalty, and party brand leadership and voting intention of the young Thai generation as hypothesis follows:

H6: Party brand attitude has a significant relationship with voting intention

H7: Party brand attitude mediates on the relationship between party brand image, party brand awareness, party brand quality, party brand loyalty, party brand leadership and voting intention

\section{Methodology}

The quantitative methodology was adopted in the research and analyzed the collected data by using multiple and simple linear regression, conditional process mediation techniques to examine the regression of voting intention in each components of party brand equity. The questionnaire using Five-Point Likert scale, range from " 1 " is Strongly Disagree to "5" is Strongly Agree. The questionnaires were distributed on young Thai generation aged 15 to 29 years in the Hat Yai district, Songkhla province, Southern Thailand.

According to Songkhla Provincial Statistical Office (2017), the number of young generation in the Hat Yai District is 84,648. This number was referred as population of the research. The research was applied Slovin's formula to calculate sample size;

Formula

$$
\begin{gathered}
n=\frac{N}{1+N e^{2}} \\
n=\frac{84648}{1+84648 \times\left(0.05^{2}\right)}
\end{gathered}
$$

So, the research has 400 respondents. The majority of respondents are age 15 to 19 years with $37 \%$. The majority of respondent are female with $56.5 \%$. The respondent's academic qualification is bachelor degree with $41.6 \%$ and occupation of respondent is student with $54.3 \%$. Finally, the three main popular social media platforms accessed by respondents are Facebook with $27.4 \%$ followed by, YouTube with $20.1 \%$ and Facebook Messenger with $19 \%$.

\section{Data Analysis}

The research analyzed the data by using the Statistical Package for the Social Sciences or SPSS. The descriptive statistics administrated by mean and standard deviation techniques. Then, Cronbach's Alpha measured reliability of the entire variables, the descriptive statistics and reliability information presents in Table 1 below. 
Table 1: The Information of Descriptive Statistics and Reliability

\begin{tabular}{|l|c|c|c|}
\hline Variables & Mean & SD & Reliability \\
\hline PBI & 3.28 & .628 & .909 \\
\hline PBA & 3.32 & .623 & .910 \\
\hline PBQ & 3.30 & .637 & .908 \\
\hline PBL & 3.27 & .669 & .909 \\
\hline Variables & Mean & SD & Reliability \\
\hline PBLS & 3.33 & .647 & .911 \\
\hline PBAT & 3.30 & .678 & .911 \\
\hline VT & 3.30 & .689 & .910 \\
\hline
\end{tabular}

Note: PBI is party brand image, PBA is party brand awareness, PBQ is party brand quality, PBL is party brand loyalty, PBLS is party brand leadership, PBAT is party brand attitude and VT is voting intention.

Regression analysis is a technique of statistic to evaluate the cause-effect, the reason and result relation (Uyanık \& Güler, 2013). Therefore, regression technique is appropriate to this research. The analysis information presents in Table 2 as follow:

Table 2: The Analysis Information

\begin{tabular}{|l|c|c|c|}
\hline \multicolumn{1}{|c|}{ Model } & B & t & Sig. \\
\hline PBI & .326 & 5.214 & .000 \\
\hline PBA & .350 & 6.029 & .000 \\
\hline PBQ & .249 & 4.018 & .000 \\
\hline PBL & .175 & 3.057 & .002 \\
\hline PBLS & .356 & 7.217 & .000 \\
\hline PBAT $^{*}$ & .823 & 27.689 & .000 \\
\hline
\end{tabular}

Note: Dependent variable is voting intention. *PBAT was analyzed by simple linear regression.

The analysis information above relates to hypothesis, as follow:

H1: Party brand image has a significant relationship with voting intention $(\beta=.326, t=5.214$, $\mathrm{p}<0.05)$.

$\mathrm{H} 2$ : Party brand awareness has a significant relationship with voting intention $(B=.350, \mathrm{t}=$ $6.029, \mathrm{p}<0.05)$.

H3: Party brand quality has a significant relationship with voting intention $(B=.249, t=4.018$, $\mathrm{p}<0.05)$.

H4: Party brand loyalty has a significant relationship with voting intention $(\beta=.175, t=3.057$, $\mathrm{p}<0.05)$.

H5: Party brand leadership has a significant relationship with voting intention $(B=.356, t=$ 7.217, $\mathrm{p}<0.05)$.

H6: Party brand attitude has a significant relationship with voting intention $(\beta=.823, \mathrm{t}=$ $27.689, \mathrm{p}<0.5)$.

Conditional process analysis is a technique of statistic to analyze mediation and moderation model (Hayes, 2012; 2018). The simplest and appropriate model for the research is model 4 analyze a mediator $\mathrm{M}$ causal located between independent variable $\mathrm{X}$ and dependent variable Y (Hayes, 2018). The model 4 presents as follow: 


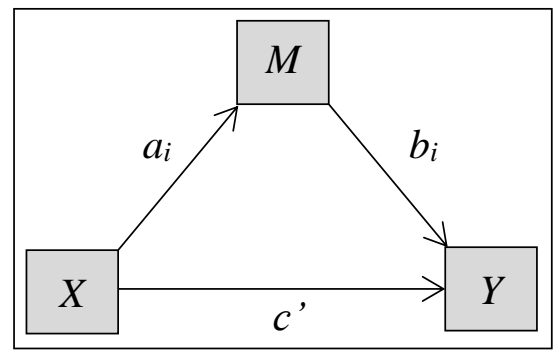

Figure 1: The Model 4 of Conditional Process Mediation Analysis

The analysis information of the mediation effect of party brand attitude on the relationship between party brand image, awareness, quality, loyalty, leadership and voting intention shows in Table 3 below.

Table 3: The Information of Conditional Process Mediation Analysis

\begin{tabular}{|c|c|c|c|}
\hline Model & $\beta$ & s.e. & Sig. \\
\hline \multicolumn{4}{|l|}{ Party brand image } \\
\hline $\mathrm{PBI} \rightarrow \mathrm{PBAT}^{\mathrm{a}}$ & .7011 & .0430 & .000 \\
\hline $\mathrm{PBI} \rightarrow \mathrm{VT}^{\mathrm{c}^{\prime}}$ & .2969 & .0400 & .000 \\
\hline $\mathrm{PBAT} \rightarrow \mathrm{VT}^{\mathrm{b}}$ & .6572 & .0370 & .000 \\
\hline \multicolumn{4}{|c|}{ Party brand awareness } \\
\hline $\mathrm{PBA} \rightarrow \mathrm{PBAT}^{\mathrm{a}}$ & .7350 & .0416 & .000 \\
\hline $\mathrm{PBA} \rightarrow \mathrm{VT}^{\mathrm{c}^{\prime}}$ & .2651 & .0426 & .000 \\
\hline $\mathrm{PBAT} \rightarrow \mathrm{VT}^{\mathrm{b}}$ & .6768 & .0394 & .000 \\
\hline \multicolumn{4}{|l|}{ Party brand quality } \\
\hline $\mathrm{PBQ} \rightarrow \mathrm{PBAT}^{\mathrm{a}}$ & .7826 & .0377 & .000 \\
\hline $\mathrm{PBQ} \rightarrow \mathrm{VT}^{\mathrm{c}}$ & .3600 & .0436 & .000 \\
\hline $\mathrm{PBAT} \rightarrow \mathrm{VT}^{\mathrm{b}}$ & .5869 & .0409 & .000 \\
\hline \multicolumn{4}{|l|}{ Party brand loyalty } \\
\hline $\mathrm{PBL} \rightarrow \mathrm{PBAT}^{\mathrm{a}}$ & .7308 & .0367 & .000 \\
\hline $\mathrm{PBL} \rightarrow \mathrm{VT}^{\mathrm{c}^{\prime}}$ & .3176 & .0410 & .000 \\
\hline $\mathrm{PBAT} \rightarrow \mathrm{VT}^{\mathrm{b}}$ & .6098 & .0404 & .000 \\
\hline \multicolumn{4}{|c|}{ Party brand leadership } \\
\hline $\mathrm{PBLS} \rightarrow \mathrm{PBAT}^{\mathrm{a}}$ & .8137 & .0343 & .000 \\
\hline $\mathrm{PBLS} \rightarrow \mathrm{VT}^{\mathrm{c}^{\prime}}$ & .3281 & .0473 & .000 \\
\hline $\mathrm{PBAT} \rightarrow \mathrm{VT}^{\mathrm{b}}$ & .5914 & .0452 & .000 \\
\hline
\end{tabular}

The analysis information above relates to hypothesis, as follow:

H7: Party brand attitude has a significant mediates on the relationship between party brand image, party brand awareness, party brand quality, party brand loyalty, party brand leadership and voting intention.

\section{Discussion}

Political branding of a political party has a significant influence on voting intention of young generation in the Southern Thailand. Consistent to several statements and research findings of scholars mentioned that political branding impacts the decision making, vote intention, vote 


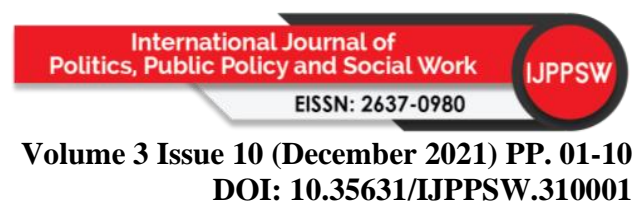

behavior of the electors (Achor et al., 2017; Butler \& Powell, 2013; 2014; Farhan \& Ahmad, 2016; Nielsen \& Larsen, 2014; Thongteerapharb, 2014).

The components of party brand equity are party brand image, party brand awareness, party brand quality, party brand loyalty and party brand leadership of the political party have a significant relationship on young generation voting intention in the Southern Thailand. The research founding confirms statement of Alkhawaldeh and Halim (2016) and Almohammad (2014) and Scammell (2007), party brand equity influence on voting intention and vote behavior of the electors.

Likewise, party brand image has a significant influence on young generation voting intention refer to statement of Alkhawaldeh and Halim (2016), the political party leader and political party image impact on voting intention. Party brand awareness has a significant relationship on young generation voting intention. Relatively, Alkhawaldeh et al. (2016b), party brand awareness has strongly impact on vote decision. Party brand quality has a significant influence on young generation voting intention. Similarly, Alkhawaldeh et al. (2016b) and French and Smith (2010) proposed that party brand quality and the perceived quality are important factors impact on voting intention.

Party brand loyalty has a significant relationship on young generation voting intention. Ahmed et al. (2017) and Campbell (1960) and Dick and Basu (1994) and Schofield and Reeves (2015) identified that party brand loyalty is attract the perception of the electors, impacts the decision making. And, party brand loyalty has strongly influence on vote intention. Party brand leadership has a significant influence on voting intention. Along the same lines, Busch (2016) reported, the strong political party standing position impacts reduce confusion of the electors.

The regression of voting intention indicates that party brand leadership has the greatest influence on voting intention $(\beta=.356)$, party brand awareness $(\beta=.350)$. This is followed by party brand image $(\beta=.326)$, party brand quality $(\beta=.249)$ and party brand loyalty $(\beta=.175)$.

\section{Implications, Limitations and Recommendation}

The research was distributed questionnaires during the gathering of teenager political crisis 2020 which influences the strong response of respondents. The political branding is the new perspective of respondent impact on the understanding in the several questions in the questionnaire. Moreover, the precise of research finding depend on politics historical and the population in the country.

\section{References}

Achor, Princewell. N., Nwachukwu, Chima. P., \& Mirian, Udensi. I. (2017). Political Branding/Brand Personality and Voters' Choice of Candidate: An Empirical Inquiry into 2015 Presidential Election in Nigeria. Journal of Marketing and Consumer Research, 37, 1-15.

Ahmed, M. A., Lodhi, S. A., \& Ahmad, Z. (2017). Political brand equity model: The integration of political brands in voter choice. Journal of Political Marketing, 16(2), 1-62.

Alkhawaldeh, A. M., Salleh, S. M., \& Halim, F. B. (2016a). An empirical study in voting behavior and political brand. International Business Management, 10(18), 4365-4372.

Alkhawaldeh, A. M., Salleh, S. M., \& Halim, F. B. (2016b). Brand equity and brand loyalty: New perspective. International Review of Management and Marketing, 6(4), 722-730. 
Alkhawaldeh, A., \& Halim, F. (2015a). The Role of CBBE in Building Loyalty to Political Brand: A Proposed Framework. Australian Journal of Basic and Applied Sciences, 9(35), 77-88.

Alkhawaldeh, A., \& Halim, F. (2015b, December). Relationship Between Brand Awareness, Brand Commitment and Brand Loyalty in the Political Marketing Context. In Conference on Business Management Research II (CBMR II 2015) School of Business Management, Universiti Utara Malaysia (Vol. 6010).

Alkhawaldeh, A., \& Halim, F. (2016). Linkages between Political Brand Image, Affective Commitment and Electors Loyalty: The Moderating Influence of Reference Group. International Journal of Business and Commerce, 5(4), 18-36.

Almohammad, A. H. (2014). The Conceptualisation and Operationalisation of Emotion-based Political Brand Equity. Journal of Marketing Management, 2(2), 165-194.

Areepermporn, P. (2019, February 26). Revealed background of Thai Rak Thai party and Future Forward logos. Revealed strategy of design in Thai politics. Thailand/Art and Design/Politics. The standard news. https://thestandard.co/thailand-political-partieslogo-design/

Bhatta, R. P. (2016). Social media and brand attitude: An empirical study on social media campaigns of corporate brands in Nepal. Advances in Economics and Business Management, 3(6), 591-596.

British Broadcasting Corporation. (2019a, April 6). Thailand election: Future Forward's Thanathorn faces sedition charges. British Broadcasting Corporation.https://www.bbc.com/news/world-asia-47837622.

British Broadcasting Corporation. (2019b, March 28). Election result 2019: Election commission announce election result 100\% public ballots of Palang Pracharath Party gathering 8.4 million. British Broadcasting Corporation News, Thailand.https://www.bbc.com/thai/thailand-47730271.

Busch, K. B. (2016). Estimating parties' left-right positions: Determinants of voters' perceptions' proximity to party ideology. Electoral studies, 41, 159-178.

Butler, D. M., \& Powell, E. N. (2013). Understanding the Party Brand, 1-46. Retrieved from papers3://publication/uuid/72C029EA-5BF3-4041-BF00-F25FB9AE633A.

Butler, D. M., \& Powell, E. N. (2014). Understanding the party brand: experimental evidence on the role of valence. The Journal of Politics, 76(2), 492-505.

Campbell, A. (1960). Converse, PE Miller, WE And Stokes, DE (1960). The American Voter. Ann Arbor.

Chang, Y., \& Ko, Y. J. (2014). The brand leadership: Scale development and validation. Journal of Brand Management, 21(1), 63-80.

Chiu, W., \& Cho, H. (2019). E-commerce brand The effect of perceived brand leadership on consumers' satisfaction and repurchase intention on e-commerce websites. Asia Pacific Journal of Marketing and Logistics.

De Landtsheer, C. L., \& De Vries, P. (2015). Branding the image of a fox: The psychological profile of EU president Herman Van Rompuy. Journal of Political Marketing, 14(1-2), 200-222.

Dick, A. S., \& Basu, K. (1994). Customer loyalty: toward an integrated conceptual framework. Journal of the academy of marketing science, 22(2), 99-113.

Farhan, A., \& Ahmad, A. (2016). A Review of Political Branding Research. Global Journal of Business and Social Science Review, 4(2), 22-29.

French, A., \& Smith, G. (2010). Measuring political brand equity: a consumer oriented approach. European Journal of Marketing, 44(3-4), 460-477. 


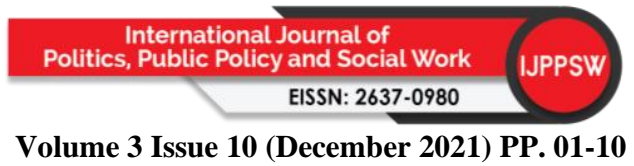

Volume 3 Issue 10 (December 2021) PP. 01-10 DOI: 10.35631/IJPPSW.310001

Future Forward Party. (2018a). About us Future Forward Party. https://en.futureforwardparty.org/about-fwp/future-forward-party.

Future Forward Party. (2018b, September 28). New future you can choose. Facebook.https://www.facebook.com/pg/FWPthailand/about/?ref=page_internal.

Guzmán, F., Paswan, A. K., \& Van Steenburg, E. (2015). Self-referencing and political candidate brands: A congruency perspective. Journal of Political Marketing, 14(1-2), 175-199.

Harris, P., \& Lock, A. (2001). Establishing the Charles Kennedy brand: a strategy for an election the result of which is a foregone conclusion. Journal of Marketing Management, 17(9-10), 943-956.

Hasuwannakit, S. (2019, May 17). To democrat party on the crossroads. Facebook.https://www.facebook.com/supathasuwannakit/photos/a.2061 $03979928404 / 499901617215304 /$ ?type $=3 \&$ theater .

Hayes, A. F. (2012). PROCESS: A versatile computational tool for observed variable mediation, moderation, and conditional process modeling, 1-39.

Hayes, A. F. (2018). Partial, conditional, and moderated moderated mediation: Quantification, inference, and interpretation. Communication Monographs, 85(1), 4-40.

Kannika, N. (2019). Different generations have different attitude. Super Poll Thailand, (August 2019),

https://storage.googleapis.com/wzukusers/user17406417/documents/8c5d55ac705743

8ab1bdae2ead95d33b/Super\%20Poll\%20\%E0\%B8\%84\%E0\%B8\%99\%E0\%B8\%95

\%Е0\%В9\%88\%Е0\%B8\%B2\%Е0\%В8\%87\%Е0\%B8\%A7\%Е0\%B8\%B1\%Е0\%B8\%

A2\% 20\%Е0\%B9\%83\%Е0\%B8\%88\%Е0\%B8\%95\%Е0\%B9\%88\%Е0\%B8\%B2\%Е0 $\% \mathrm{~B} 8 \% 87 \% \mathrm{E} 0 \% \mathrm{~B} 8 \% 81 \% \mathrm{E} 0 \% \mathrm{~B} 8 \% \mathrm{~B} 1 \% \mathrm{E} 0 \% \mathrm{~B} 8 \% 99$.pdf.

Kudeshia, C., \& Kumar, A. (2017). Social eWOM: does it affect the brand attitude and purchase intention of brands?. Management Research Review.

Marland, A. (2013, June). What is a political brand?: Justin Trudeau and the theory of political branding. In annual meeting of the Canadian Communication Association and the Canadian Political Science Association, University of Victoria, British Columbia, June (Vol. 6).

McCargo, D. (2019). Southeast Asia's Troubling Elections: Democratic Demolition in Thailand. Journal of Democracy, 30(4), 119-133.

Melewar, T. C., Small, J., Andrews, M., \& Kim, D. (2007). Revitalising suffering multinational brands: an empirical study. International marketing review.

Nielsen, S. W., \& Larsen, M. V. (2014). Party brands and voting. Electoral Studies, 33, 153165.

Olarn, K., \& Mackintosh, E. (2019, April 6). Popular Thai party leader charged with sedition. CNN News. https://edition.cnn.com/2019/04/06/asia/thailand-election-thanathornsedition-charges-intl/index.html.

Olsen, M. C., Slotegraaf, R. J., \& Chandukala, S. R. (2014). Green claims and message frames: how green new products change brand attitude. Journal of Marketing, 78(5), 119-137.

Phipps, M., Brace-Govan, J., \& Jevons, C. (2010). The duality of political brand equity. European Journal of Marketing, 44(3-4), 496-514.

Pich, C., \& Armannsdottir, G. (2018). Political brand image: an investigation into the operationalisation of the external orientation of David Cameron's Conservative brand. Journal of Marketing Communications, 24(1), 35-52.

Pradhan, D., Duraipandian, I., \& Sethi, D. (2016). Celebrity endorsement: How celebritybrand-user personality congruence affects brand attitude and purchase intention. Journal of Marketing Communications, 22(5), 456-473.

Copyright $\odot$ GLOBAL ACADEMIC EXCELLENCE (M) SDN BHD - All rights reserved 


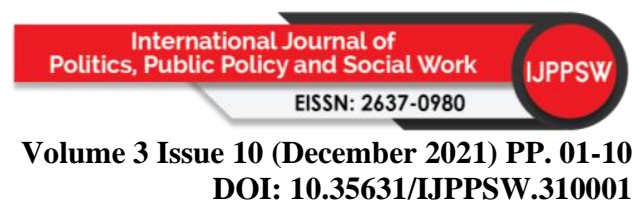

Regan, H., \& Olarn, K. (2019, March 24). Thailand's youth demand change ahead of elections. Cable News Network. CNN News. https://edition.cnn.com/2019/03/22/asia/thai-election-young-votersintl/index.html.

Scammell, M. (2007). Political brands and consumer citizens: The rebranding of Tony Blair. The Annals of the American Academy of Political and Social Science, 611(1), 176-192.

Schofield, P., \& Reeves, P. (2015). Does the factor theory of satisfaction explain political voting behaviour?. European Journal of Marketing, 49(5-6), 968-992.

Songkhla Provincial Statistical Office. (2017). Songkhla Provincial Statistical Report. Lerwitee Press.

Suaib, E., Jusoff, K., Abdullah, M. Z., Zuada, L. H., \& Suacana, I. W. G. (2017). The effect of the party's image relationship to voters' satisfaction and voters' loyalty. International Journal of Law and Management, 59(6), 1013-1028.

Suyitno, D. N. (2013). Success Stories of Political Marketing in Multi Ethnic Societies : Case Studies Jokowi-Ahok in Jakarta and Aher-Deddy in West Java 1, (June), 1-22.

The office of the Election Commission of Thailand. (2019b, March 28). List of candidates in highest popular votes per provincial of electorate representative in general election (The $\begin{array}{lll}\text { current information } & \text { March 2019). }\end{array}$ https://www.ect.go.th/ewt/ewt/ect_th/download/article/article_20190328165029.pdf.

Thongteerapharb, W. (2014). A Study on Thai Voters' Attitude towards Political Marketing and Branding: A Case of The Democrat And Pheu Thai Parties, Thailand. In Faculty of Management Science, Silpakorn University. Thailand The 2014 WEI International Academic Conference Proceedings. Budapest, Hungary.

Upadhyaya, M., \& Mohindra, V. (2012). Political branding in India. Journal of Politics and Governance, 1(4), 4-12.

Uyanık, G. K., \& Güler, N. (2013). A study on multiple linear regression analysis. ProcediaSocial and Behavioral Sciences, 106, 234-240.

Vogel, A. T., \& Watchravesringkan, K. (2017). Consumer evaluations of trend imitation: brand equity, consumer attitudes and preference. Journal of Product \& Brand Management.

Wongratanawin, P. (2018, November 1). Future Forward Party whose future?. Bangkok Post. https://www.bangkokpost.com/opinion/opinion/1568350/future-forward-party-whosefuture-. 